\title{
THE ENFORCEMENT OF CHILD LABOR LAWS
}

\author{
By E. N. Clopper, Ph.D.,
}

Secretary for Northern States, National Child Labor Committee, New York City.

The National Child Labor Committee has renewed its campaign in behalf of the federal child labor bill, which will go before the sixty-fifth Congress enjoying the prestige of its overwhelming endorsement by the last House. It provides four standards already quite generally recognized by the individual states: an age limit of fourteen years for employment in mills, canneries, workshops and factories; (2) a minimum work day of eight hours for children between fourteen and sixteen in such establishments; (3) the prohibition of work at night in such places on the part of children between these ages; and (4) an age limit of sixteen years for employment in mines and quarries. The power of Congress to regulate commerce among the states is invoked with the object of imposing these standards upon manufacturers and mine operators who ship their products from state to state-a provision virtually all-inclusive. For those who refuse to meet these requirements, suitable penalties in the form of fines or imprisonment are provided.

At present twenty-seven of the states have the first standard already written in their laws without weakening exemptions, while seventeen others have adopted it in principle but permit a lower standard under certain conditions. Eighteen states rigidly require the second standard, while four others make exceptions. The third standard is widely recognized, as no fewer than thirtythree states insist upon this elementary provision for the protection of working children, and five others have adopted it with exemptions. The fourth standard affects only those states with mining or quarrying industries, and has been incorporated in the laws of twenty-two, three of these, however, authorizing departures from its observance.

Hence it is clear that the federal bill does not seek to force new and untried restrictions upon the employers of the country, but, on the contrary, is intended simply to establish firmly and apply 
uniformly a few of the first principles of child protection which have already been found practicable by many of the states. It will serve to bring the legislation of laggard states up to the level of the others and to wipe out the advantage in labor cost which employers of children in backward communities now have over their competitors elsewhere because of the lower standards under which they are permitted to operate. In other words, it will help to destroy special privilege in the exploitation of children, and bring our practice more into harmony with the national conscience.

A vital feature of the measure has, however, escaped comment in spite of the quite general interest which the bill has awakened, a feature without which the proposed law would be worthless, and if enacted is destined to work a revolution in our administration of child labor laws-the provision for enforcement.

In our efforts to establish social justice we have been passing laws to remedy conditions and neglecting to make use of them. We seem to be under the impression that our laws are automatic and that each in its own field will remedy any given situation by the power of its own virtues if we will only have patience and let it have its way. Legislation is looked upon as the great specific for social ills; but its properties are narcotic. Whenever we feel outraged over any abuse we immediately exclaim, "There ought to be a law to prohibit that," but if assured that one is already on the books we at once subside, and our faith in the self-acting quality of legislation restores our equanimity. Most of us have observed that when two friends board a street car and each insists upon paying the fare for both, if one should rashly say he has tickets, the other pockets his coin and lets his companion pay, serene in the delusion that the tickets relieve him of all further concern about the matter.

The majority of our state legislatures meet biennially, several hold annual sessions and all are occasionally called out of the regular season to act in emergencies, and their product is a bewildering mass of "social legislation"-some of it bad, much of it good, most of it well-meaning, but all of it lacking in the essential element of simplicity. In terms of the country at large, our present labor laws, for example, are in hopeless confusion. We have been admiring the vast product of our legislative mills, innocently believing that the evil aimed at was run through the body the moment 
the governor's signature was attached to an act, and those who take part in getting a law always come away from the state capitol in smug satisfaction, as from a funeral, feeling that everything has been done for the departed that could be done.

The child labor laws of the several states may be things of beauty as they repose on the statute books, but they are certainly not joys forever because they are not enforced. A few years ago a model child labor law was drafted by the National Committee and endorsed by the United States Commissioners on Uniform Laws; in the exuberance of its new statehood Arizona actually swallowed it whole, but omitted to provide any means for its enforcement, and to this day the act is merely ornamental. An older commonwealth, indeed, North Carolina, one of the thirteen original states, still denies to its Commissioner of Labor the authority to compel obedience to even its wretchedly inadequate law. And these are only instances of widespread indifference.

It stands to reason that a federal law must be enforced by federal authority, and accordingly the bill which has been before Congress lays upon all United States district attorneys the duty of prosecuting violators in the federal courts upon complaint of any federal, state or local officer or private individual, who may present satisfactory evidence of infringement.

The words "federal courts" hold the promise of a better day. So far, on the rather rare occasions when prosecutions for violation of state child labor laws have been brought, the proceedings have been necessarily instituted in local courts, usually before minor magistrates like the justices of the peace, and in this fact lies a great obstacle to effective administration. Local courts are subject to and often controlled by local prejudices and considerations of expediency. The judges hold their positions through local influence or the local vote and in arriving at decisions in cases affecting powerful local interests a sadly large number follow the line of least resistance. Their failure to uphold the law is the cause of extensive child exploitation and the source of the discouragement which often destroys the efficiency of state officers. No matter how complete and conclusive may be the evidence gathered by a factory inspector, it is frequently held for naught by a court that fears to offend an influential defendant, or the punishment inflicted is so ridiculous as to invite more flagrant disobedience. 
Officers charged with child labor law enforcement in the most enlightened communities commonly complain that in many of the courts it is almost impossible to secure convictions for violation and that, when convicted, the defendant is either fined the minimum sum fixed by law or released under suspended sentence. Accounts of their experiences are well-nigh incredible. In one case the judge advised the defendant to change his plea from "guilty" to "not guilty" and when this happy suggestion was acted upon, at once dismissed him. In another case the judge declined to hear the complaint because the employer charged with the offense was an old friend of his, a touching instance of simple faith and loyalty worthy of a place in our school readers. Sometimes zealous factory inspectors are even denounced by the court for annoying "our best citizens."

It is the policy of labor inspectors at first to warn employers concerning breaches of the law and to resort to prosecution only after repeated warnings have been disregarded and evidence of violation is clear and convincing. But when the employer is finally haled into court the almost invariable result is either dismissal with a warning from the bench because "it is the defendant's first offense," or imposition of the minimum fine. This minimum is often absurd, especially when the law provides that the offender shall be fined "not more than" a certain sum, in which case the court by no means infrequently visits calamity upon the head of the malefactor to the extent of one dollar! The deterrent effect of this punishment is not altogether apparent, inasmuch as the employer derives profit from the labor of children because of the low wages they command, and could continue his illegal practices and pay such nominal fines as a regular charge against his business without suffering any financial loss.

In an official report of the Commissioner of Labor for New York we read that, in spite of positive proof of twenty-seven violations of the labor laws by manufacturers of a certain class of goods, the state factory inspectors were unable to obtain conviction in a single case. The report solemnly asserts that judges and juries in farming communities will not uphold the labor laws; in discussing the general problem of enforcement it remarks that responsibility was placed by the legislature upon the courts as well as upon the department of labor, and ironically adds, "How the 
courts are doing their part can be seen from an examination of the prosecutions of the past year."

The Commissioner then invites attention to the large percentage of dismissals and suspended sentences following prosecutions for second and even third offenses. "In one case we alleged third offense against a telegraph company and although the evidence was conclusive, the case was dismissed by the judge who made excuses for the good intentions of the company."

As an illustration of the lengths to which a fear-infected court will go in the effort to shield a powerful local interest from embarrassment, there is the perennial controversy between the New York department of labor and the upstate canners over the employment of young children. Formerly the state child labor law forbade the employment of children under fourteen years of age "in or in connection with any factory." The canners nevertheless put such children to work preparing fruit and vegetables for the canning process, carefully placing them in sheds not adjoining the factory itself. The inspectors were not dismayed by this adroit maneuver, however, and appealed to the state's attorney general for a ruling, whereupon that erudite official opined that the Iaw in question was not applicable to the sheds. The local courts were guided by this ruling and child labor abuses grew apace in the canning industry. Then a remedy was sought in the legislature and the legal definition of a factory was amended so as to include "all buildings, sheds, structures, or other places used for or in connection" with a factory, while the employment of children under fourteen was prohibited in or in connection with any factory or for any factory at any place in the state. But the canners had not exhausted their resources and refused to be coerced. They erected tents and set the little children to work inside snipping beans; at one cannery under a single tent, a factory inspector recently found 180 children under fourteen, some of whom were under ten. Subsequent events proved that the canners had not reckoned without their host, for, although four different proceedings were instituted against this company for these violations, in every case the complaint was dismissed!

And at another cannery where such children were also at work under a tent, the manager calmly admitted the illegality of their employment, assuring the inspector that the company was never- 
theless quite willing to assume the risk. That the risk was not excessive appears from the acquittal of the company in the three prosecutions brought against it for these same violations. In another case the defendant naively interpreted the law to his own advantage, testifying that the tent was not connected with the factory - that indeed the place where the children had gathered was a "circus tent," and the jury was so impressed by this profound exegesis that it wasted no time in rendering a verdict of not guilty. These and many other facts about this travesty of justice are all officially set forth in the latest report of the New York department of labor just issued. Verily the canners are a canny lot!

The passage of the federal bill could not fail to improve the situation. It is undeniable that federal authority commands greater respect than state or local authority. Employers who disregard with impunity a state labor law would in all probability obey a federal law, for the prospect of acquittal through influence in the federal courts is far more remote than in local tribunals. The federal judges and district attorneys are appointed by the President and presumably disinterested in proceedings against "leading citizens," while county and municipal magistrates are elected by vote of the people they are called upon to judge and are more or less directly associated with local political organizations whose policies are largely dictated by the employing class.

A federal child labor law would enable state factory inspectors to refer their most obstinate cases to the United States courts, as practically every manufacturer engages to some extent in interstate commerce, and it goes without saying that the chances for conviction would thereby be very greatly enhanced. The penalties would most certainly have a more restraining effect-one cannot conceive of a federal court going through the burlesque of imposing a one dollar fine. Furthermore, such a law would insure a modicum of protection for working children in states where enforcement is unknown, inasmuch as federal inspectors would be authorized to investigate conditions in all the industries affected, and the spirit of laissez-faire in child labor reform would suffer a body blow. 